\title{
The Last Steamboat Whistle: the Rise and Demise of Chilliwack Landing at Skwah First Nation, 1863 - $1928^{1}$
}

\section{Merlin Bunt and Trevor Williams}

\begin{abstract}
À l'époque coloniale, Chilliwack Landing était un port d'escale prospère de la rivière Fraser pour les bateaux à vapeur fluviaux situés le long des rives, lesquelles s 'érodaient rapidement. Le rapport entre la croissance de Chilliwack et la période de 60 ans pendant laquelle les bateaux à vapeur ont ouvré à partir de Chilliwack Landing est en grande partie inexploré en raison de la complexité de sa situation dans la réserve de Stó:lō de la Première nation Skwah. La disparition éventuelle du port est survenue après l'apparition de systèmes de transport plus efficaces, tels que les trains et les véhicules, mais elle a également été précipitée par la montée en puissance de Centreville comme nouvelle priorité commerciale de Chilliwack et les problèmes associés au travail pendant les cycles saisonniers d'envasement et d'inondation à la Première nation Skwah.
\end{abstract}

Young Jack Henderson would wait, and finally spot the steamer "coming around the mountain, and he would run, run like the devil, run all the way down there, and they would lift him up and take him onto the boat." He said "They called me Steamboat Jack!" Henderson recalled the activity on the Stó:lo reserve at Skwah in the 1880s, at Chilliwack Landing, how when "the whistle would blow [...] what a scattering of farmers, screaming ladies, teams running away, and three or four fellows running after them!" Another Chilliwack Landing resident recalled "the two Chinese shacks owned by Gee Yuean and Jim Kee," and pioneer shopkeeper George Ashwell, "and another man named Henderson, they lived one side of the building, one the other," sharing their location at Chilliwack Landing in the 1880s. Part of the settler oral

\footnotetext{
${ }^{1}$ Readers are asked to note two things. First, this essay does not speak for or represent the views of the Stó:lo Tribal Council or Skwah First Nations. Second, it is based in part on oral history interviews, in some instances conducted years ago. If the subjects used the term "Indian," now considered archaic, it has been retained where direct quotes or formal titles are involved; the authors regret any offence this may cause.
}

The Northern Mariner/Le marin du nord, XXVII, No. 3 (July 2017), 267-288. 
history recalled how "trouble between Capt. John Irving ... and the Ashwells over the question of agencies resulted in the establishment of a third store at the Landing. Captain Irving built the store and appointed John Henderson as manager." Young Jack recalled how the Canadian Pacific Navigation steamers would land right at Henderson's store, how he "was always on the dock to pull line in when the boat docked", and the riverboat crew, perhaps Capt. John Irving himself, "used to call me Steamboat Jack ... up to when I was 8 years old!"2

\section{An Introduction to Chilliwack Landing}

Chilliwack Landing is a name from the old geography of the Fraser Valley, one from colonial-era British Columbia. This predecessor to Centreville (subsequently renamed Chilliwack) was home to a modest commercial storefront, and was a social hub for many years for settlers and First Nations alike. Chilliwack Landing at Skwah First Nations was a remote outpost, but it maintained daily contact with larger centres, such as Victoria and New Westminster, through steamboat travel. "In the late '80s, Chilliwack Landing was one of the busiest places on the river," recalled one eyewitness, and through the 1870s and 1880s, "Landing Road, now known as Wellington Avenue, was the busiest road in the district. It fanned out into four other roads which served several parts of the district." The geography lent itself as the best location for steam-powered riverboats to load and unload cargo, and for passengers

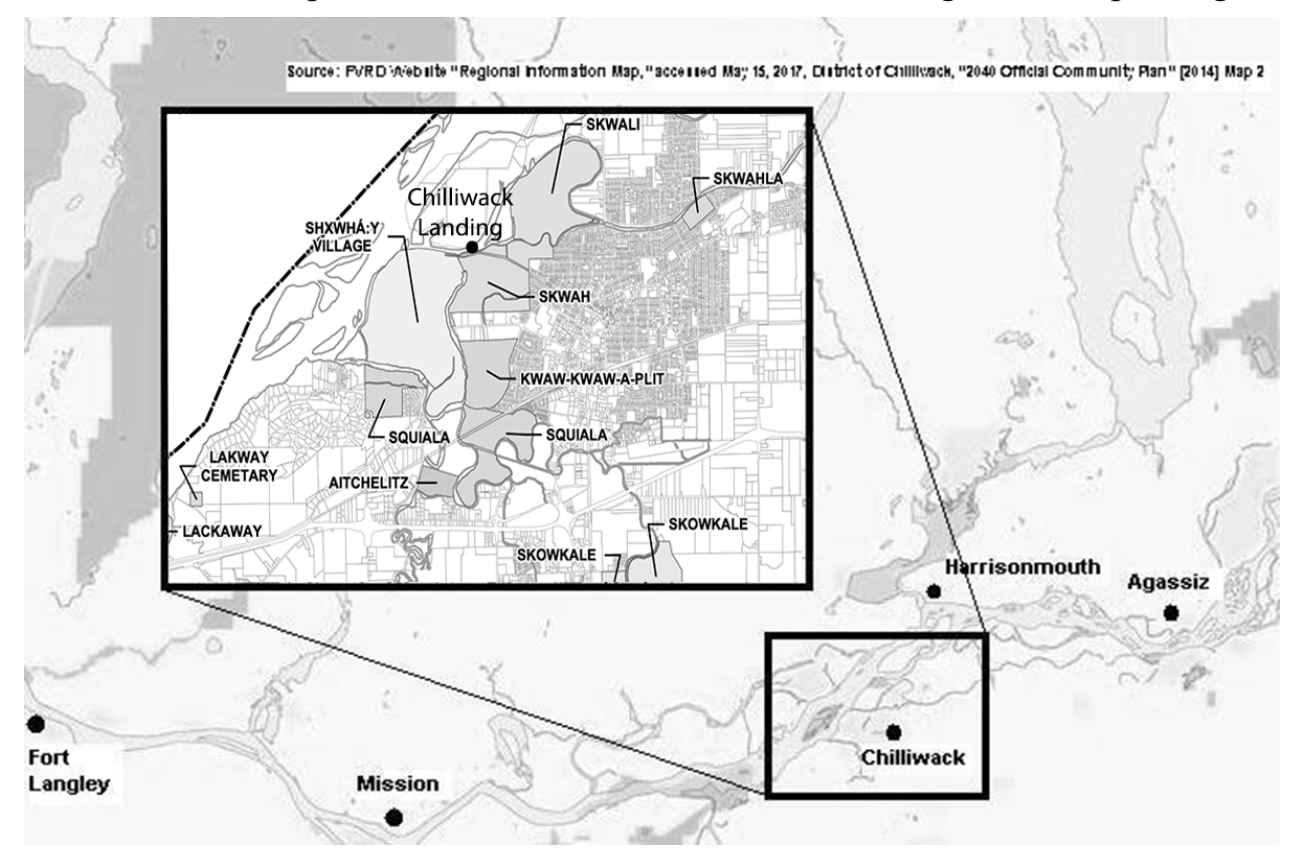

\footnotetext{
${ }^{2}$ Interview Reuben Nowell, Chilliwack Archives (CA), Chilliwack, BC, Add MSS 127, side 1; interview Jack Henderson, British Columbia Archives, Victoria, BC, PR-0374 (Imbert Orchard Fonds), T0718 side 1; interview Mrs. K. Mellard, BC Archives PR-0374, Item T0716 sides 1 and 2; Chilliwack Progress (CP) 30 April 1958; 9 CP 21 May 1941.
} 
to embark to points beyond, but the Landing was also a favoured settlement location for generations of First Nations groups. Chilliwack Landing was strategically located, at the halfway point between Hope and Fort Langley, between the commercial centres of Yale and New Westminster, as well as at the junction of a number of rivers and sloughs, and was always a focal point due to several small, year-round First Nations settlements on both sides of the Fraser River. Residents were members of the Pilalt tribe. They were connected with bands living around the Harrison River and upstream on the Fraser River to Seabird Island, but collectively all regional First Nations call themselves "Stó:lō ," or "people of the river."”

Many primary and secondary historical sources are hesitant to state that Chilliwack Landing was located on a Stó:lō First Nations reserve, while the few sources which correctly admit this have difficulty articulating what this means or why this matters. The chiefs of Skwah were influential in early Chilliwack, and one current of Chilliwack Landing history includes stories of the struggle of these chiefs to reclaim their property rights on reserve lands. The effects of evolving natural threats of sandbars, land erosion, and seasonal flooding to steamboat travel from the First Nations reserve are also interwoven into this story. They resulted in docks being wiped out or cut off by sandbars, and warehouses gradually falling apart, rotting, or floating away. The public road through the reserve was often unpassable, and had a decidedly unmaintained look.

Riverboat captains often used Chilliwack Landing in an impromptu fashion, with on-the-spot decisions made regarding where to land or load, depending on river conditions and the time of season. It is better to imagine the Chilliwack Landing location very generally, as a variety of landing locations throughout Skwah reserve were used at different periods. However, what these many landing locations have in common is they were almost all either along the south shore of Hope Slough, or the nearby shore of the Fraser River, and most were located within the boundaries of Skwah First Nation. While the Landing served as the gateway to Chilliwack for many decades, it sported an undeveloped or incomplete looking First Nations reserve vernacular. This condition was accepted by nineteenth-century Chilliwack settlers, but early twentieth- century Chilliwack residents generally were embarrassed and ashamed of it. Not surprisingly, the variety of these secondary themes outlined in this paper which enlighten Chilliwack Landing's history are complicated and have been misunderstood. Local historians have found it easier to omit mention of this prominent aspect of early Chilliwack history. However, evidence would suggest that Chilliwack Landing and Skwah First Nations are one and the same place.

\footnotetext{
${ }^{3}$ Mrs. M.A. Kenney to Matthews, 11 April 1958,Vancouver City Archives (VCA), File 815, Folder 168; CP 13 December 1950.
} 


\section{Settlers, Steamboats \& Colonial-era Chilliwack Landing}

The beginning of the steamboat era at Chilliwack Landing was an uncertain period for the local Stó:1ō as their coveted reserves in desirable locations were under threat of being taken from them. "The spectre of forced resettlement on communal reserves was a constant terror for the Stó:1ō," noted Dr. Keith Carlson, while historian Chad Reimer has more recently articulated the loss of reserve lands of Stó:lō bands in the nearby Sumas district. Such sentiment is recalled by Isaac Kipp's brother, Henry Kipp, who "wanted them to take all the Indians out of the valley altogether." A recurring theme at Chilliwack Landing is the popular historical narrative of First Nations-settler relations in British Columbia prior to Confederation with Canada. It is a pattern of First Nations groups losing control of lands in favoured and previously inhabited locations to new settlers through land pre-emptions. Before retiring in 1864, British Columbia Governor James Douglas asked government surveyor William McColl to survey generous First Nations reserves through the Lower Fraser Valley. The emergence of a distinct reserve at Skwah First Nation occurred three years after the McColl surveys when large reserves were "reduced to what is necessary for the actual use of the natives," by Joseph Trutch when he was the lands and works commissioner. These "Trutch reductions" occurred throughout British Columbia, and generally set the boundaries of reserves as they are today, including those in the Chilliwack area. According to Stó:lō elders, "the name Skwah means you go through something, like you go through the fence or something," a definition which describes Skwah First Nation as being the traditional entrance and exit point by water to Chilliwack Prairie. ${ }^{4}$

Prior to 1863, it was uncommon to see a steamboat stop where the Hope Slough met the Fraser River. Those low-draft, steam-powered riverboats tended to call on the north side of the Fraser River, at Harrisonmouth, where the two competing routes to the goldfields in the British Columbia interior diverged. The Douglas route traversed Harrison River and Harrison Lake, and on through a string of lakes to Lillooet, while the Fraser Canyon route used the Fraser River up to Yale, then to Lillooet over a dangerous mountain road. Early hotels and a store opened at Harrisonmouth at Skowlitz First Nation for riverboat travellers. The opening of the Cariboo Wagon Road, connecting Yale with Lytton and Clinton, in 1862 meant riverboats, and travellers, began to prefer the Fraser Canyon route to Yale and on to the British Columbia interior, and abandoned the Douglas route to the goldfields. Steamboats began stopping more frequently at Chilliwack Landing for food, wood,

\footnotetext{
${ }^{4}$ K.T. Carlson, "The Power of Place, the Problem of Time: A Study of History and Aboriginal Collective Identity," (unpublished PhD thesis, University of British Columbia (UBC), 2003), 245, 297; C. Reimer, "Sumas Valley at Confederation: Assault on the Semá:th Homeland," British Columbia History (Spring 2017), 14-22; interview James Kipp, BC Archives PR-0374, T0308, sides 1 and 2; R. Fisher, "Joseph Trutch and the Indian Land Policy," BC Studies 12 (Winter, 197172), 11; interview Sam Louie, CA MSS 362 File 259.
} 
and lodging instead of Harrisonmouth, and the first generation of rudimentary stores appeared at Skwah First Nation. ${ }^{5}$

New settlers had been trickling onto the lush and wooded Chilliwack Prairie, inland from Chilliwack Landing, to homestead and to join settlers already living among the Stó:1ō. The river frontage north of Skwah First Nation, near what would later become Minto Landing, was proposed for a town location in 1862 by P.J. Leech of the Royal Engineers. An influx of additional settlers and goods began around 1863, and one settler in particular, Isaac Kipp, pre-empted land in the area which he, and likely his Stó:lō neighbours, began industriously working, and soon he was leasing land at Chilliwack Landing and using it as a steamboat gateway to export farm produce on a scale not seen before. Historian Ron Meyer, perhaps describing Isaac Kipp's circumstance, noted that Fraser Valley "settlers who did not have a road or river link to market were at considerable disadvantage." Colonial officials Col. R.C. Moody and Governor James Douglas had previously set aside various waterfront locations throughout the Fraser Valley in 1859 as a government reserve for lease to settlers willing to invest in dock or landing facilities. Through the 1860s and 1870s, the lease of government reserve land at Chilliwack Landing was recorded on maps, such as figure 2, which depicts "Kipp's Landing.",

The settlement pattern at Chilliwack Prairie was reoriented with the 1863 arrival of Isaac Kipp. Chilliwack area history commonly begins by venerating this significant landholder, but Isaac Kipp's interconnectedness with the Stó:lō is normally excluded by his various biographers. Frank Kipp recalled his father speaking Halq'eméylem fluently, "rather than the simpler Chinook tongue," and characterized his father as "a well-loved crony of many of the Indian leaders," one who often attended Stó:lō potlatches before the federal government banned the practice. By 1866, Kipp's farm output dwarfed that of his combined neighbours, which implied a meaningful relationship with the First Nations reserves, people who readily helped in his labour-intensive farming endeavours. The Stó:lō stakeholders in early Chilliwack likely would not have assisted to such an extent if Kipp had not reciprocated that goodwill. ${ }^{7}$

For several reasons, in 1863 Chilliwack Landing became a port of call for river steamers travelling between New Westminster and Yale. This location, and the immediate vicinity hosted several longstanding, year-round Stó:lō settlements, complete with cedar longhouses, Kekuli dwellings, burial sites, as well as being a favoured Stó:lō fishing location. Skwah First Nations had long been a venue for large Stó:lō gatherings, as well as a resting place for people travelling along the

\footnotetext{
5 D. Sleigh, The People of the Harrison (Abbotsford, BC: Abbotsford Printing, 1990), 50, 69, 70.

${ }^{6}$ R.H. Meyer, "The Evolution of Roads in the Lower Fraser Valley" in AS.H. Siemens ed., Lower Fraser Valley: Evolution of A Cultural Landscape (Vancouver: Tantalus, 1968), 76; Leech to Moody, 14 November 1862, BC Archives, GR-1327 File 974/1; Moody to Douglas, 12 April 1859., BC Archives, ibid., File 915/23.

7 BC Archives, S. Cuthbertson, “Isaac and Mary Kipp” (mss,1982) I clippings file "Kipp, I”; J. Gibbard, "Early History of the Fraser Valley, 1808 - 1885," (unpublished MA thesis, UBC, 1937), 198; CP 28 November 1951; British Columbian, 15 September 1866.
} 
Fraser River. Another factor underlying the congregation of people at Chilliwack Landing was the Stó:lō canoe culture, which dominated locally in the 1860s; people living around Skwah First Nation actively travelled in their canoes throughout the region, and generally provided transportation to the Chilliwack settlers upon request. ${ }^{8}$

\section{Storekeepers, Canoes \& Riverboat Crews}

The early Fraser River steamboats both complemented and competed against the vessels of the Stó:lō canoe culture, similar to the later interplay between steamboats and trains. The well-documented fluctuations in prices charged for steamboat freight and passage by riverboat companies (as outlined throughout the works of historian Norman Hacking) increased the appeal for less wealthy new settlers to ask the Stó:lō for assistance in moving people and goods. Many Chilliwack pioneers recounted first arriving in Chilliwack by a canoe guided by Stó:lō, versus only a few by steamer. Boatbuilding and river travel for the Stó:lō living around Chilliwack Landing were aspects of deeply entrenched cultural behaviour prior to the arrival of steamboats, and the common local use of these canoes lasted "well into the twentieth century," according to Dr. Keith Carlson. These transportation practices were a well-known means of transport used by the Hudson's Bay Company to move goods from remote trading posts to shipping centres. ${ }^{9}$

During the 1860s, Chilliwack Landing became a port of call for boats full of settlers, merchants, and miners destined for Yale, many travelling on to the interior goldfields. The pantheon of old-time steamboat captains, such as Jack Deighton, John Irving, and Bill Moore, guided their famous steamboats up to the shore and spent time at Chilliwack Landing. Many of the sternwheeler riverboats did not have sleeping accommodation or kitchens. Thus they stopped for meals or sometimes to stay the evening, depending on their own schedules and the conditions of the Fraser River. This commercial opportunity ushered in the age of businesses situated at Chilliwack Landing starting with Robert Garner's store in $1865 .^{10}$

Garner later sold his store to John Shelford, a storekeeper around Skwah First Nations for several years. Hudson's Bay Company correspondence addressed to Shelford refers to Chilliwack Landing as "Shelfordville" through 1869, and Shelford pre-empted one of the islands immediately north of Skwah First Nations in 1870. Shelford was described as "a man living on the town reserve at Kipp's Landing," by stipendary magistrate Henry Maynard Ball in 1869, but the 1868 field notes of British Columbia government surveyor J.B. Launders designated Kipp's Landing, the future Chilliwack Landing, as a government reserve carved distinctly from

\footnotetext{
${ }^{8}$ K. Carlson, ed., You are Asked to Witness: The Stó:lō in Canada's Pacific Coast History (Chilliwack: Stó:lō Heritage Trust, 1997), 8, 9, 168.

9 Ibid; N. Hacking, "Steamboating in the Fraser in the 1860s" British Columbia Historical Quarterly 10:1 (January, 1946), 18.

${ }_{10}$ CA MSS 714, File 4; Gibbard 289; Note: CA MSS 1, File 142 indicates a "Mexican" storekeeper preceding Garner.
} 
Skwah First Nations. Shelford was "consequently liable to pay ground rent" to the colonial government each month to live at the Landing. Shelford was later asked, in spring 1870, by Ball if "instead of paying rent" to the colonial government, if he would like a private, surveyed lot from the government reserve at Skwah First Nations to be subdivided for him. However, Lands and Works Commissioner Joseph Trutch declined to sell Shelford the land with no reason offered except that he did "not think it worthwhile to lay out this reserve into town lots." "1

Despite failing to sell land at the government reserve at Chilliwack Landing, Captain Henry Ball (as he was also known) was not finished with diminishing the Skwah reserve. In 1869, Ball declared a second land dedication, "a public landing for the convenience of the white settlers in the neighbourhood," located at "the northeast corner of the reserve, on Hope Slough and the Fraser River." Jonathan Reece noted how by 1875 Ball's dedication at "Squy [sic] Landing" had "gone down the river by washing away." A later set of maps of Skwah reserve completed by surveyor Captain Jemmett in 1879 shows Kipp's Landing without a special dedication, and confirms that the original five-acre public landing declared by Ball was located way out in the Fraser River due to erosion by the river. Despite a precise location, Chilliwack settlers viewed these pre-Confederation declarations as authorizing steamboats to land somewhere within the boundaries of the diminishing reserve. The government reserve at Kipp's Landing, and Ball's declaration of a public landing formed the basis for the free and easy, near-public use of Skwah Reserve until $1928 .{ }^{12}$

One benefit of boats visiting the reserve was that relationships were established between band members, crew members and riverboat captains, which ultimately led to many from Skwah First Nation working on the Fraser River as steamboat crews. First Nations people in general dominated the steamboat crews throughout the Fraser River. Alfred Hawkins, a Chilliwack resident, recalled of the nineteenth century riverboat crews, how "a lot of them were Indians, some white men." Chilliwack historian A.C. Wells recorded the Stó:1ō elder Albert Louie discussing how one particularly strong band member from Skwah received his English surname connected with the Chilliwack Landing steamboats: "he worked on a boat when my Dad [in the] early days when the boat used to run from Westminster to Yale, and he used to pack a lot of heavy stuff, you know, and the boys then they call him 'muscle.' That's why [he] got that name and he was Mussell all the time." "13 Several generations from the Garner family connected to Skwah First Nations also

\footnotetext{
11 Tolmie to Shelford, 15 April 1869 \& 28 September 1869, Hudson's Bay Company Archives, Winnipeg, (HBCA), B.226/b/42, microlfilm reel 1M247; Pre-emption 738. 3 March 1870, BC Archives GR-112, Vol 95, File 216; Natural Resources Canada, "Old Field Notes, Fraser and Kamloops Agencies” Survey Notebook FBBC162, Launders, JB, 1868, 144; 26 April 1870, Ball to Trutch \& Pearce to Trutch, BC Archives GR-1372, F-102, File 4a,.

12 Farwell to Sproat, 12 May 1880, Library and Archives Canada, Ottawa (LAC), RG10 Vol 11028, File SRR2; Reece to Lenihan, 6 August 1875, LAC, RG10 Vol 1001.

13 CA, MSS 362, File 259.
} 
maintained lifelong relations to riverboats in British Columbia. They got their start at Chilliwack Landing. ${ }^{14}$

\section{Gilbert Sproat Returns Chilliwack Landing to Skwah First Nations}

Through the late 1870s, the Canadian government sponsored an Indian Reserve Commission. A delegation led by Gilbert Sproat travelled throughout British Columbia to mediate land-use conflicts between First Nations and settlers. On first arriving at Chilliwack in late 1878, the original five-acre public dedication for a riverboat landing had long been swept away, and the core of businesses and portable houses at Chilliwack Landing had been creeping eastward along the south bank of Hope Slough to stay ahead of the land being eroded by the Fraser River. What Sproat encountered was unusual, but conforms to the local long-term pattern of settlers (future Chilliwack residents) on this First Nations reservation conducting business, investing resources, and feeling quite at home at Chilliwack Landing in amongst the Skwah band members. ${ }^{15}$

During his visits to the Chilliwack Landing area reserves, Sproat witnessed for himself the Fraser River's power to erode and redeposit soils: "Between December 1878 and April 1879, a large wash took place and the store [...] had to be moved back several hundred feet." The municipal council asked Sproat to use his position as the reserve commissioner to recommend to the provincial and federal governments that a new steamship landing be built, but later, "after various conversations with councillors and settlers it seemed best to leave matters as they were, owing to the uncertainty of the river." Commissioner Sproat accepted the advice of his surveyor, A.S. Farwell, who believed that regardless of where the river channel moved in the future, that Chilliwack Landing and Skwah First Nations would ultimately be washed away. Although declining to act, Gilbert Sproat and the Indian Reserve Commission did something fortuitous for Skwah band members before leaving Chilliwack: in his written decision on behalf of the commission, Sproat omitted any reference of any subdivision, government reserve, or any other special land designation for Chilliwack Landing in his legal description of the Skwah reserve boundaries. From this point onwards, thanks to Gilbert Sproat, Chilliwack Landing was sealed into the boundaries of Skwah First Nations. ${ }^{16}$

Despite Centreville being surveyed and developed in 1881 and Sproat's changes to Chilliwack Landing in 1880, there were many great years ahead for this steamship landing, largely due to corporate entities. Norman Hacking believed the large

\footnotetext{
${ }^{14}$ Interview Alfred Hawkins, BC Archives, PR-0374 Item T0712-1\&2; CA MSS 362, File 259; G. White, "The Development of Eastern Fraser Valley," British Columbia Historical Quarterly 12:4 (October,1948), 266; CA MSS 743 File 1; verbal communication between Mrs. J. Cromarty and authors, fall 2015.

15 McMillan to Powell 30 March 1880, LAC RG10 Vol 11028, File SRR2; Farwell to Sproat 12 May 1880, LAC RG10 Vol 11028, File SRR2.

${ }^{16}$ Sproat to Powell, 13 May 1880, LAC RG10 Vol 11028, File SRR2; Farwell to Sproat, 12 May 1880, LAC RG10 Vol 11028, File SRR2; Decision 15 May 1879, “Chilliwack Indians, Skwah Subgroup" LAC RG10 Vol 11028, File SRR2.
} 
increase in the riverboat trade on the Fraser River associated with Canadian Pacific Railway (CPR) construction began in 1880, when work started at Yale, British Columbia, and this milestone event marked the beginning of river steamers being a common sight at Chilliwack Landing. The SS Cassiar, SS William Irving, and SS Pacific Slope were among the boats which shoved up against the shores at Skwah, close to the stores of their local agent. The following year investors joined steamship magnate William Irving and the Hudson's Bay Company to form the Canadian Pacific Navigation Company. Historian Ron Meyer noted how the arrival of the CPR "replaced water transport on the north side of the valley" and at Yale, "almost as soon as it was completed." The most significant effect of the CPR's arrival was that after its trains began operating in 1886 and "ruining steamboating on the Fraser," Chilliwack Landing became the eastern terminus on the Fraser River for steamers from New Westminister for over thirty years. ${ }^{17}$

In the 1880s Chilliwack Landing most resembled a small village. Storekeeper Shelford was replaced by New Westminster merchant George Ashwell and hoteliers Jane McDonald and Matilda Harrison and set up to cater to the steamboat trade. One resident told Vancouver archivist Major S. Matthews how at the riverboat landing she did not recall a wharf, but "there were several small buildings owned by early settlers" in amongst the businesses and Skwah band members. An entire generation of settler children, such as young "Steamboat Jack" Henderson, grew up amongst the bustle at Skwah reserve, in the shadow of the sternwheelers. By the end of the 1880s, the Landing Road was the "busiest road in the district," and Gilbert Sproat noted how the future Wellington Avenue was "used by the whole settlement, as it leads to the steamboat landing.","18

\section{The Effect of Indian Agents on Chilliwack Landing}

Through the late 1880s, Indian agents exercised more control over First Nations reserves through regulations gradually added to the Indian Act. These key colonial officials worked to clear the Chilliwack area reserves of all non-members. The social venues of hotels, stores, and restaurants at Chilliwack Landing were encouraged to move eastward to Chilliwack, the "new" town centre. With fewer reasons to linger at the Landing, new commercial proposals to move people from Chilliwack Landing appeared, such as an 1891 initiative to build a tram between Upper Chilliwack Landing and the new town. The Chilliwack Tramway Co. was formed by local

\footnotetext{
17 N. Hacking, "British Columbia Steamboat Days, 1870 - 1883," British Columbia Historical Quarterly 11:2 (April,1947) 88, 96, 99; P. Roy, "The Changing Roles of Railways in the Lower Fraser Valley," in A.H. Siemens, ed., Lower Fraser Valley: Evolution of A Cultural Landscape (Vancouver: Tantalus, 1968), 51; Meyer 76; A.J. Johnson, "The Canadian Pacific Railway and British Columbia, 1871 - 1886," (unpublished MA thesis, UBC, 1936), 179; E.W. Wright, ed. Lewis and Dryden's Marine History of the Pacific Northwest (Portland, OR: Lewis and Dryden Printing, 1895), 217.

18 Kenny to Matthews, 11 April 1958, VCA, MS Matthews Collection (00816), File \#168; Sleigh, 75; Memorandum, Sproat to Powell, 16 April 1880, LAC RG10 Vol 11028, File SRR-2.
} 
shareholders, for "constructing, operating, and maintaining a street railway or tramway within the limits of the municipality of Chilliwack." Council supported this project, and the tramway company conducted a survey and held a ceremonial public sod-turning event in conjunction with the sale of Chilliwack town lots in 1891, but the Chilliwack Tramway never materialized. ${ }^{19}$

As elsewhere in Canada, the regional Indian agent wrestled financial control away from band members within Skwah First Nation. This meant rent payments from businesses and residents at Chilliwack Landing that used to be paid directly to band members went to the agent. By the mid-1880s, Indian Agent McTiernan was collecting just under $\$ 200$ of rent annually from people living and working at Chilliwack Landing. Records of payments from Chilliwack Landing business owners show when each vacated Skwah First Nation. Shopkeeper John Henderson left in April 1889, hotelier and livery owner Matilda Harrison re-located to Chilliwack in 1891, while longtime business owner George Ashwell stopped paying for reserve facilities in March 1891. But hotel owner Jane McDonald was still located at Chilliwack Landing as late as $1890 .^{20}$

The chief of Skwah, Chief "Captain"' George, leased his allotment to longtime Chilliwack shopkeeper George Ashwell in 1881 or 1882. A decade later, the subsequent Indian agent Frank Devlin describes how Chief George "has made a demand on me to have all the money refunded to him...that no other Indian has any right to this money but himself." Devlin explained how lease money collected was credited to the entire band, but found Chief "George is not satisfied with this, and insists that the money belongs to him, and not to the band." Devlin, however, was fearful of other Skwah band members making similar claims against the Steamboat owners or Chilliwack Landing merchants who had become accustomed to paying rent directly to the agent, as "their lots are claimed by other Indians." Gradually Devlin learned about the regime of land allotments at Chilliwack Landing, how "The Skwah Indian reserve has been divided among the different members ... through the Chief, assisted by the principal men of the tribe, years ago," and was surveyed by Gilbert Sproat and the Indian Reserve Commission in 1878. Devlin acquiesced, and began forwarding rent money directly to band members in accordance with this grassroots land ownership regime whose origin roughly coincides with the start of riverboats using Chilliwack Landing. ${ }^{21}$

\section{Captain Powers, Prohibition and 1890s Chilliwack Landing}

When the SS Gladys, owned locally by Captain Richard Powers from Sumas and Charles Martin from Harrisonmouth (amongst other owners), began sailing from Chilliwack Landing in early 1891, this steamer, known as "Old Reliable," joined a

\footnotetext{
${ }^{19}$ CP 21 April 1891; CP 7 May 1891; CP 14 May 1891; CP 16 July 1891; CP 30 July 1891; Roy 56.

${ }^{20}$ LAC RG10 Vol 3778, File 39055; CP 16 April 1891.

${ }^{21}$ Devlin to Vowell, 15 October 1892 \& Memo, G. Ashwell, 22 September 1894, LAC RG10 Vol 3778, File 39055; CP 21 May 1941.
} 
crowded field. Three riverboats already served the New Westminister - Chilliwack route, which is a statement to the demand for produce grown in the southern Fraser Valley. November 1892 saw the opening of the New Westminster Farmers Market, and large sternwheel steamboats such as the Delaware, William Irving, along with the smaller Courser, each left Chilliwack Landing with full cargoes. By 1895, the Gladys had established a reputation of "holding rates lower than the lowest continuously," and gained the "Farmers Friend" nickname for special travel arrangements: "If you didn't have the money, you could always work your way.",22

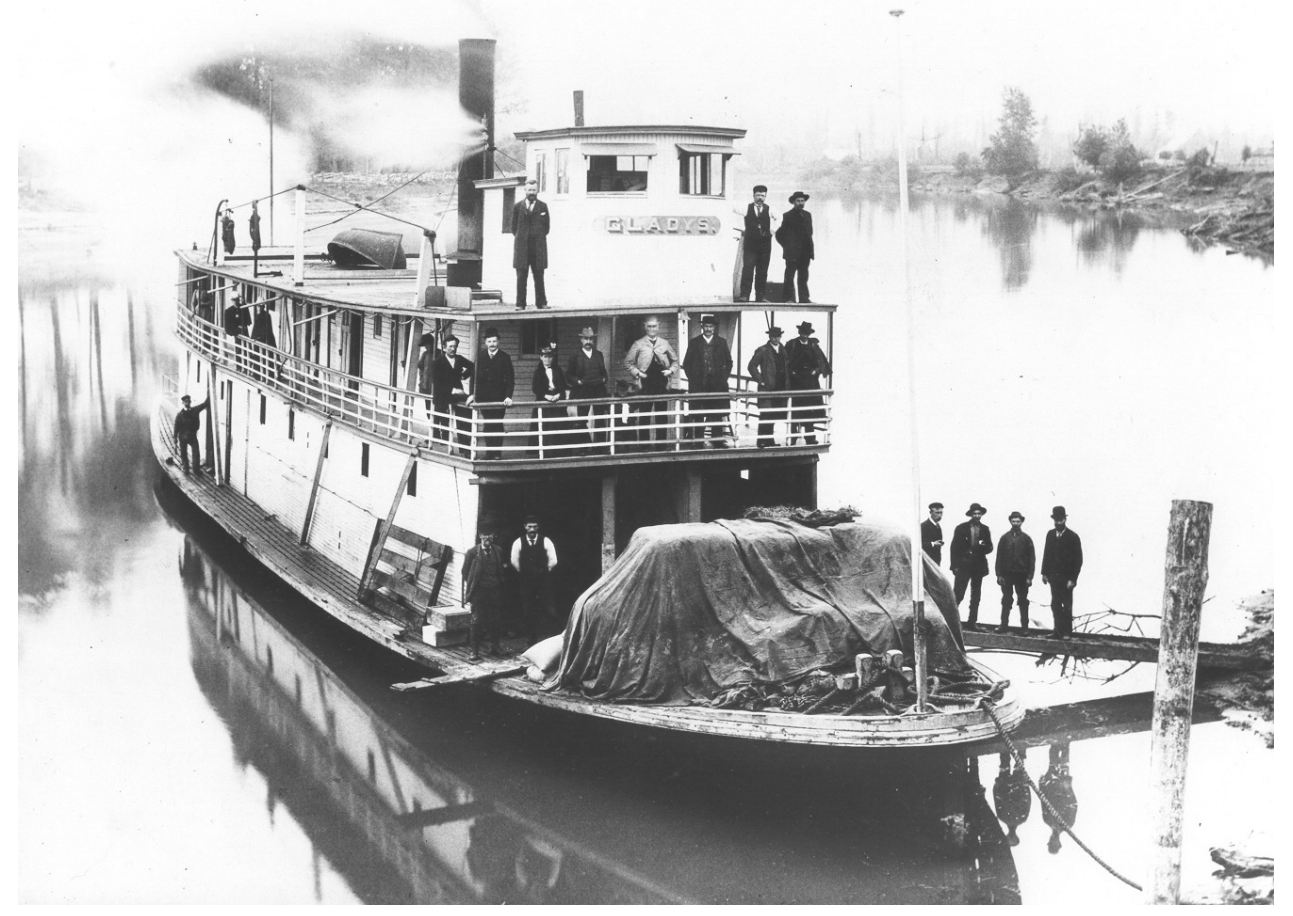

Photograph courtesy of the New Westminster Public Library, photo 189,

Date: [ND] Source: Barbara Lyle, donor

Through the 1890 s, the "prohibition controversy was always a prominent public issue in Chilliwack," according to local historian Robert Smith. Chilliwack "displayed temperance enthusiasm almost from its inception," mustering large majorities in favour of alcohol prohibition whenever a plebiscite was offered to

22 B. Mather, New Westminister, The Royal City (Vancouver: Kingstone, 1958), 101; CP 21 January 1892; Charlie Power interview, tape 3, sides 1 and 2, CA MSS 401; CP 27 February 1895; Sleigh, 85. 
voters, or protesting against liquor licenses brought before the municipal council. In this context, Chilliwack Landing had a role in the controversy. Riverboat crews were a reliable source for alcohol from outside communities, which brought additional scrutiny by local prohibitionists. Chilliwack's zeal to press charges against alcohol smugglers even swept up old-time riverboat Captain Ashbury Insley when law enforcement officials opened criminal proceedings against him in 1892 . Many of the 1890s river steamers sometimes seemed to function as floating saloons, as some boats would merely sail out into the Fraser River to avoid the local ban on alcohol sales. Most locals knew which boats served alcohol and which ones did not. One settler recalled how Chilliwack residents bought their liquor from the crews of river boats that stopped at Chilliwack Landing on their way up and down the Fraser. With boats like the Gladys, Transfer and the William Irving "the townspeople would hurry to the landing by car or on horseback to greet friends, pick up supplies, and replenish their liquor stock." 23

The Fraser River offered some a life's career and relationship with Chilliwack Landing. In 1896 Captain Powers promoted his mate Charlie Seymour to the status of riverboat captain, in command of the Gladys. This was the first of many commands Seymour had during his forty-two year career in riverboats. Seymour, born in 1862 in Montreal, arrived in British Columbia in 1887 where he worked on steamers in the Thompson and Shuswap regions, before coming to the lower mainland in 1889 as part of the crew in steamers travelling between Chilliwack and New Westminster. Although in 1914 biographers Howay and Scolefield called Seymour a "loyal son of New Westminister," he would become the captain most closely identified with Chilliwack Landing. ${ }^{24}$

After losing the "Farmers Friend" Gladys to the 1898 fire at New Westminster, Powers appealed unsuccessfully to Chilliwack investors for a modern boat. Even though SS Royal City was "secured at a bargain, the Captain says his losses have been so heavy that he cannot manage the purchase alone," and his rented warehouses at Skwah First Nations were returned to Chief George. Nonetheless Powers was soon back with other boats. He introduced the Royal City to Chilliwack Landing as a temporary boat from October 1898 until it burned at Mission, British Columbia, in April 1901, again with Charlie Seymour in command. Meanwhile, Powers sought an even bigger boat. He introduced one of the longest boats (second in size to the William Irving) on the Fraser River to work the Chilliwack - New Westminster run, the SS Ramona. Table 1 illustrates how large the Ramona was compared to other boats that came to Chilliwack Landing. ${ }^{25}$

\footnotetext{
23 R. Smith, "Bibles and Booze: Prohibition in Chilliwack in the Late 1800s," British Columbia Historical News 12: 3 (1979), 6; R. Campbell, Demon Rum or Easy Money: Government Control of Liquor in British Columbia from Prohibition to Privatization (Ottawa, Ontario: Carleton University Press,1991), 17; CP 28 September 1949; CP 20 May 1896; CP 14 April 1892.

${ }^{24}$ CP 20 May 1896; CP 19 May 1897; F. Howay and E.O.S. Scholefield, British Columbia from the Earliest Times to the Present, III, (Vancouver: SJ Clarke, 1914), "Capt. Charles E Seymour," 833-4.

${ }^{25}$ CP 28 September 1898; CP 12 October 1898; CP 17 April 1901; Devlin to Chief George, 30 May 1898, LAC RG10 Vol 1453; CP 2 August 1899; White, 267; Sleigh, 80.
} 
The Ramona was not a lucky vessel. Two weeks after purchasing her, Powers and his mainly First Nations crew from Chilliwack Landing were killed when the boilers blew up near Fort Langley in April 1901. The Ramona explosion was a uniquely Chilliwack tragedy involving a captain from Sumas, on a riverboat that called Chilliwack Landing home, with a crew drawn mainly from members of Skwah First Nations. The boat was so large it was not wrecked by the explosion. She was soon repaired and back into service from Chilliwack Landing. Given the volume of river traffic, Fraser Valley historian George White called that first decade of a new century "the heyday of the sternwheeler" on the Fraser River. In 1903 the Ramona collided with the railway bridge at Mission, British Columbia while waiting for SS Hamlin to pass under the narrow crossing where both riverboats had arrived at the same time. The "pilothouse was demolished." Charles Warner, a crew member of the SS Hamlin, watched "the pilothouse fold up and the stack go over. Capt. Young came out on his hands and knees and called on Capt. Bonser to look." In 1903 after she hit a snag at Greendale, British Columbia, and sank, newspapers opined that "This vessel seems to be pursued by some evil spirit", but she was repaired again and put back into service. The Ramona later rammed another bridge

Table 1: Names, Years \& Length (ft) of Steamships at Chilliwack Landing, 1863 - 1928

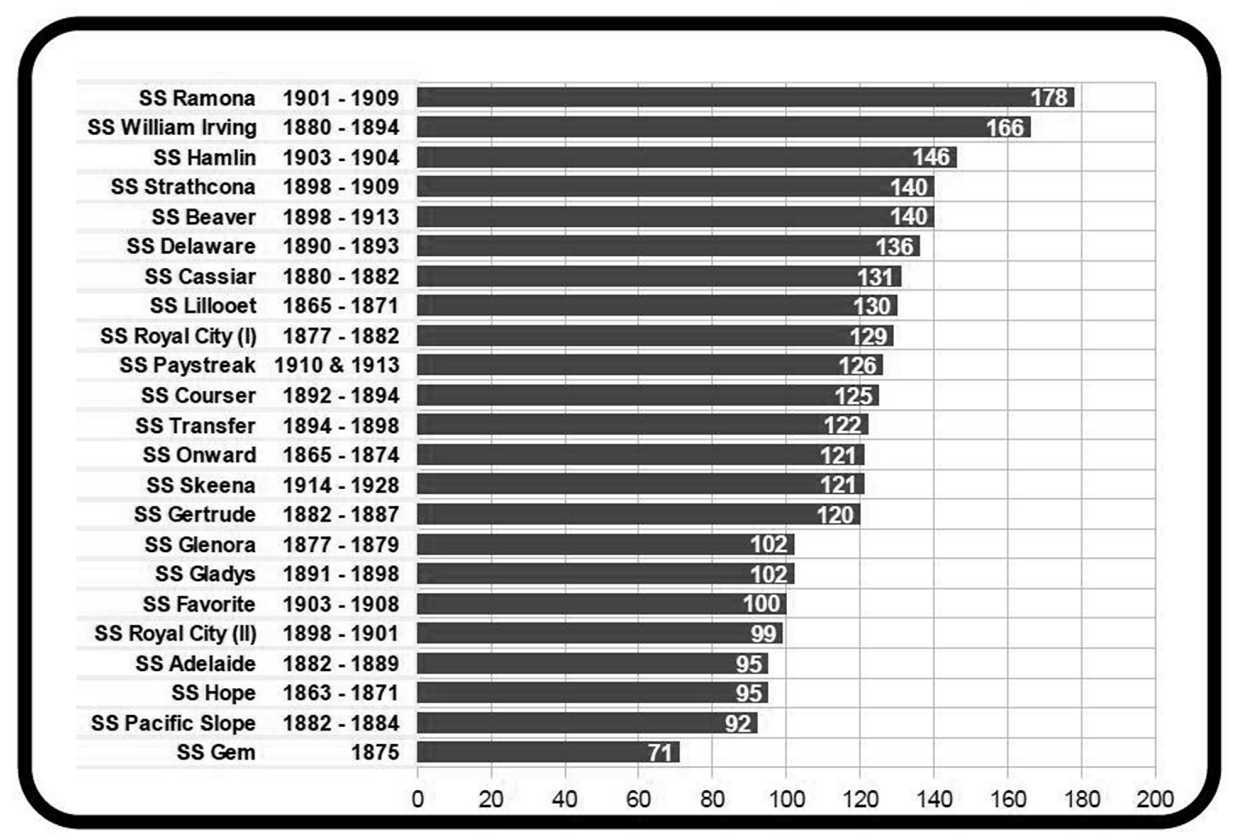

Source: Mills Marine List, Chilliwack Progress, Victoria Colonist, Mainland Guardian. (Note: Dates indicate years serving Chilliwack Landing)

at Stave River, near Whonnock British Columbia, after the throttle stuck in 1907. The following year she was run right up onto the riverbank at Glen Valley, between Fort Langley and Matsqui. Newspapers finally announced the "Last of the Steamer 
Ramona," a most accident-prone boat in April 1909, when she sank in shallow water at Port Haney. ${ }^{26}$

\section{The Abuse of Riverboat Facilities from Natural Hazards}

The Fraser River's sandbars, besides tree snags and rocks, were the natural obstacle that most tested the skills of a riverboat captain. The first mention of sandbars affecting riverboat access was in the early 1890 s, when the Nanaimo Daily Telegram announced how "up-river steamers have been unable to reach Chilliwack Landing" due to the "lowness of the water." In the 1890s the distinction of Upper and Lower Chilliwack Landing came into common use. The Upper Landing, which was roughly located around the main Chilliwack Landing site inland along Hope Slough, became hard to reach during certain times of the year due to sandbars. A lower landing closer to the junction of the Fraser River and beyond, was required to load and unload steamers. Fast-moving river sediment accumulated and dispersed quickly. An example of how actively Fraser River sediment moved is shown by one settler's recollection of how at Chilliwack Landing "he had grounded on a [sand] bar with a canoe but that in a few moments the bar had been swept away." These springtime sand accumulations brought by freshets were a natural annual occurrence on the Fraser River, where "approximately two thirds of the annual [sediment] load is transported in May and June." In the high water the Upper Landing could easily be reached by steamer. Chilliwack settlers and riverboat operators in the $1890 \mathrm{~s}$ did not yet complain about travelling the rough First Nations reserve roads to load and unload goods in the mud of the Lower Landing for most of the year. ${ }^{27}$

The conditions which created the sandbars that would later plague Chilliwack Landing began in the 1890s. Dr. G.D. McLean believed that in earlier times, each of the Fraser River sloughs (such as Hope Slough) were "actively flowing side channels," and he suggested how the later-constructed "dykes have cut off a number of major sloughs [...] which has had a major impact on the back channels" causing "infilling by fine sediments." Settler Jonathan Reece suggested in 1897 that the reason there was a shortage of water in the channel between the Upper Landing and the Fraser River was "Since the water of Vedder Creek had ceased to come this way, and Coquappel [sic] Slough had been dyked," only the Hope Slough had remained to empty into Chilliwack Landing. This too was dammed in 1892 as the beginning of what would later be the road crossing Skwah First Nations to Lower Chilliwack Landing. ${ }^{28}$

\footnotetext{
${ }^{26}$ White, 266; $C P 1$ April 1953; $C P 14$ October 1903; $C P 9$ December 1908; CP 14 August 1907; CP 28 April 1909; CP 25 March 1903; CP 25 April 1901.

27 Nanaimo Daily Telegram 13 December 1893; CP 29 December 1897: D.G. McLean, “The Relation Between Channel Instability and Sediment Transport on Lower Fraser River," (unpublished PhD thesis, UBC, 1990), 51.

${ }_{28}$ McLean, 59, 111; CP 29 December 1897.
} 
The Fraser River channel and sandbars had a reciprocal relationship; the location of the channel affected the deposition zones where sandbars formed and these same sandbars slowly influenced the movement of the channel. The Fraser River channel was actively eroding the river shore of Skwah First Nations through the decades before 1890. Silt deposit at Chilliwack Landing was not a problem as the nearby channel current was strong enough to sweep the silt away. However, the channel moved to the other side of the Fraser River in the 1890s and remained there into the early twentieth century. Instead of the banks being eroded, the Chilliwack Landing waterway now became a deposition zone for silt from the Hope Slough, and sandbars began to form. ${ }^{29}$

The public concern about the deposits of river silt at the Landing grew in the decades ahead, but Chilliwack residents in the 1890s did not let these sand obstacles dampen their confidence in the location of the riverside landing. In 1897, a public meeting was held with the British Columbia government engineer to air grievances, and to consider options for Chilliwack Landing. At that time, Chilliwack Landing was lacking in warehouse space, livestock pens, regular road maintenance, and modern dock facilities. However initiatives for a new, modern riverboat landing were ultimately rejected, with "many believing that the improvement of the present landing is both more economical and practicable." The more established settlers did not see the deficiencies of Chilliwack Landing as being important enough to supersede the pure convenience of the location for themselves and the town of Chilliwack. Storekeeper George Ashwell believed "the old landing is the most convenient for all concerned," while Isaac Kipp said he "would rather see the landing remain at the old place." However, both men lived and worked very close to the Landings; for the remainder of the community it was arduous to arrive and load at Chilliwack Landing. A more sceptical observer might ask whether these established landholders were more interested in preserving their pioneering advantage than selecting a riverboat landing located more in the community interest. Even so, the Chilliwack Progress summarized the community sentiment in its headline: "The Old Landing is Preferred by the Majority." 30

\section{Silt, Mud and Awaiting the SS King Edward}

From the perspective of the local farmers who used the riverboats and the politicians who represented them, the first decade of the twentieth century was characterized by criticism of the inadequacy of Chilliwack Landing; over time these sentiments evolved into bitterness toward the federal government for not sharing their concern. The problem of sandbars choking out the waterway grew through the decade, matched with the constant, persistent calls for the dredge ship controlled by the federal government to attend and clear the sand away. That long awaited day in April 1902 arrived and "was made a kind of civic holiday", when the dredge SS

\footnotetext{
9 McLean, 114.

${ }^{30}$ CP 29 December 1897.
} 
King Edward first appeared at Chilliwack Landing, and the ship was met by large adoring crowds. Politicians of all levels gave speeches of gratitude to the ship and captain. They would return twice before the end of the decade. Chilliwack residents ultimately wanted year-round access for riverboats to get to the Upper Landing, and not have to use the Lower Landing, which brought the riverboat customers right through the heart of the Skwah reservation to the river's shore. ${ }^{31}$

The reason commonly stated for the public not wanting to travel to the Lower Landing was having to navigate the stretch of muddy road through Skwah First Nations, which was tough "on both man and horse flesh" alike, alternatively described as "almost impassable," or "toilsome." This road grew longer as time passed, but was occasionally gravelled as were other roads in Chilliwack through the 1900s. As the Landing Road was one of the first thoroughfares submerged during flood season, the roadwork presumably vanished with each flood. The municipality hesitated to invest here because it did not "feel disposed to expend much money on that over which they have no jurisdiction." Occasionally, the criticism moved past the rough roads into a larger commentary of the appearance of the Landing on Skwah reservation. "A majority of passengers dread going in or out of Chilliwack on account of the atrocious landing," wrote the editor of the Chilliwack Progress, while describing the Lower Landing as one of "old tumbled down warehouses" which were "only fit for a backwoods town," with "mud in abundance." 32

The sheer muddiness for which the Upper and Lower Landings became famous for was also singled out for criticism. Travellers who arrived at the Landing would commonly "see the bus and freight wagons standing to the axles in mud," and required passengers to "wade through mud and water to get to their conveyance." At the Lower Landing, the Chilliwack Progress noted how steamer cargo required extra labour to be "loaded and unloaded in the mud as in the past" by the steamboat crew. Travellers also found that without a dock, "gum boots are required by the passengers to reach the boat." As Chilliwack Landing was sometimes without a wharf, mud which was "placed there by nature or heaped up by the Fraser" was used to make ramps to unload riverboats. ${ }^{33}$

Warehouses at Chilliwack Landing had a short life span, due to natural hazards. CPN owned a warehouse at the Upper Landing through most of the 1890s (perhaps earlier), an asset the company valued on its books at $\$ 330$ between 1890 and 1894 . The twin flood years of 1895 and 1896 likely damaged this warehouse significantly, lowering the value to $\$ 200$, before this warehouse vanished from the list of company assets altogether by 1898 . The new CPN boat, SS Beaver, may have moved into the warehouse formerly used by the Gladys, as Captain Powers signed over the warehouse before Indian Agent Devlin, for Chief George "for the rent which he [Capt. Powers] is owing." It is likely that the chief's re-acquired warehouse also did

31 CP 30 April 1902; CP 24 May 1905; CP 5 February 1908.

32 CP 5 September 1900; CP 24 July 1901; CP 28 May 1902; CP 13 June 1906; CP 10 September 1910; CP 5 March 1914; CA MSS 373, File 21.

${ }^{33}$ CP 1 November 1905; CP 20 September 1905. 
not last. Three years later, in December 1902, a new plan was afoot to build yet another warehouse at Chilliwack Landing. With George Ashwell in the lead, the municipality and both steamboat companies combined their funds to build a new warehouse, "entirely under municipal control", but six months later it had "taken a tumble to itself in the high water." 34

During his tenure, Chief George had arranged for Chilliwack Landing to return and remain under Stó:lo management, but he still believed up to the final months of his life that "white men [were] going to take your land from" him and relocate the Skwah reserve members. Chief George had stopped earlier Indian agents from submitting Chilliwack Landing rents to Ottawa, while the next generation of Indian agents independently negotiated leases, collected the payments from both riverboat companies, and submitted these funds directly to him and other band members. The subsequent chief, Chief Harry Stewart, discovered that the riverboat companies had special verbal agreements that had expired with Chief George in 1905, and they stopped paying for a period after the old chief passed away. Ten years later, Chief Stewart addressed the Royal Commission on Indian Reserves (McKenna McBride Commission) as the chief of five combined bands, as a chief of Chilliwack Landing. When given the platform, the popular Chief Stewart declined to comment on how Chilliwack Landing functioned for Skwah First Nation up to that time. ${ }^{35}$

\section{The 1905 Chillwack Landing Facility}

Eventually, with funding provided by the federal government, Chilliwack built a new Upper Landing in August 1905, and proudly cut the ribbon on the new facility later that fall. The new landing was located immediately east of the older Chilliwack Landing site on the Hope Slough. The Chilliwack Progress jubilantly announced how "for the first time in the history of Chilliwack the passengers from the boats are assured they can land with dry feet and free from mud!" The new steamboat landing featured a "splendid new building" with a large "spacious wharf." The new landing also provided for the Ramona and the Beaver to share a common home in the new facilities, instead of each riverboat company making its own arrangements as in the past. In addition, "the grounds around the warehouse have been nicely cleared and levelled, and with a few large cottonwoods standing here and there, the effect is very park-like." 36

\footnotetext{
${ }^{34}$ HBCA File A.12/FT213/1, microfilm reel 815; Devlin to Chief George, 9 October 1899, LAC RG10 Vol 1454; CP 10 December 1902; CP 1 July 1903.

${ }_{35}$ McDonald to Chief George, 26 March 1904, LAC RG10 Vol 1460; McDonald to Chief George, 21 December 1904, LAC, RG10 Vol 1462; McDonald to Chief Stewart, 30 December 1905, LAC, RG10 Vol 1464,; McKenna-McBride Royal Commission, Transcript of Testimonies, Meeting with the Chilliwack Band or Tribe of Indians at Chilliwack BC, 13 January 1915, 171-182, accessed August 82016 from UBCIC website [http://www.ubcic.bc.ca/ Resources/ourhomesare/index.html]. ${ }^{36}$ CP 20 September 1905; CP 25 October 1905; Canada Debates of the House of Commons 1905 Session, Vol 4, June 11 1905, 7573; McDonald to Chief Stewart, 30 August 1906, LAC RG10 Vol 1465.
} 
Within weeks of opening, the new dock was choked with sand, and a large sandbar formed at the mouth of Hope Slough, ensuring no steamboats could reach the dock. The new facility was seemingly built obsolete: "The government has given us a very good wharf but what good is it if the steamers cannot reach it?" asked the Chilliwack Progress, and public mood towards Chilliwack Landing soured yet again. The newspaper editor estimated that "It will be necessary to have the dredge at work every second week throughout the year" for the new landing to function as intended. Fingers were pointed at government engineers for the landing location at Skwah Reserve: "The people of Chilliwack did not recommend the present location for a wharf." To add to the perceived insult, the Beaver and Ramona acted together in November 1906 to collect a $\$ 0.75$ per ton penalty for any time they had to load or unload in the mud at the old Lower Landing, where "there is no warehouse or shed for the accommodation of freight." ${ }^{37}$

Previously, any critical comments the municipal government might have had about Chilliwack Landing were muted, since the Landing was outside its jurisdiction and Chilliwack had no direct financial stake there, even though the entire community used the riverboat facility. The surviving municipal budgets from the Chilliwack Council show the beginning of local public spending after the construction of the 1905 Landing site, which matches with the public qualities of Chilliwack Landing. For the remainder of that decade and afterward, Chilliwack Council contributed nominally to the riverboat landing facility by hiring staff and undertaking road maintenance. ${ }^{38}$

As a temporary measure to redress the lack of facilities, Chilliwhack Township Reeve F.C. Kickbush arranged for Chilliwack Landing to be "supplied by the government, in lieu of dredging a proper channel, with a floating dock, or a landing scow, surmounted by a warehouse, $22 \mathrm{ft}$. x $60 \mathrm{ft}$. which would be used to ferry goods from the Landing riverbank to the steamers from 1907 to 1909 . This dock was intended to be moved between points, depending on where the water level was. However, the shortcomings of this floating wharf were much publicized when it either flipped over, capsized, or failed to float. Newspapers declared Chilliwack Landing to be "the bete noir of the council, the Board of Trade, and everyone at all interested in the business of the Valley." The poor performance of Chilliwack Landing facilities was measured against the public knowledge that railway service was coming to Chilliwack. Railway companies sought franchise agreements, or permission to build, which Chilliwack voters endorsed in a 1906 plebiscite. By August 1907, the first sod was being turned in Chilliwack on the new British Columbia Electric Railway (BCER) line. ${ }^{39}$

\footnotetext{
${ }^{37}$ CP 1 November 1905; CP 13 June 1906 CP 14 November 1906.

${ }^{38}$ CA MS 373, Box 21, files "1901 - 1908," and "1908 - 1915."

${ }^{39}$ CP 25 December 1907; CP 23 October 1907; CP 15 April 1908; CP 11 August 1909; Fraser Advance 16 March 1907, CP 21 August 1907.
} 


\section{BCER Versus Chilliwack Landing Steamers}

Meanwhile, back on the Fraser River, newspapers in 1910 heralded the "Cruise of the SS Paystreak," a worthy new competitor to Chilliwack Landing's mainstay, the Beaver. This exciting new steamer had "been built expressively for the New Westminster - Chilliwack river trade," and achieved a new benchmark, with "every stick and plank in her and every ounce of machinery and equipment being manufactured and installed in the shipyards and machine shops of New Westminster." As with earlier riverboats, the crew-owned Paystreak featured a saloon for patrons, and contained all the amenities of riverboats of that age, including electric lights. Of course, teetotalers selected the dependable Beaver, the workhorse of this age, which historian George White believed to be "the finest of a long line of river-boats" at Chilliwack Landing. The Beaver was the only local boat that installed a special travelling compartment exclusively for First Nations and Asian customers. This steel-hull sternwheeler likely moved the most freight of any boat ever at Chilliwack Landing during the fifteen years it worked on the Fraser River. Seven months after the debut of the Paystreak, in the fall of 1910, the first train and freight service to and from Chilliwack officially began. ${ }^{40}$

According to historian Pat Roy, "a price war between the Railway and the steamer companies ensued" shortly after the BCER began its Chilliwack service. It would take only one year for BCER to push one of the pair of Chilliwack Landing steamers out of service. BCER managers were "asked to raise its rates by owners of Paystreak," because the independent steamer owners complained that they were having trouble earning enough profit to pay for their fuel. This appeal to BCER fell on deaf ears, and through ongoing competition, the BCER bankrupted the Paystreak. But the single surviving steamer Beaver would not soon go away. The effect of railway service in Chilliwack was more directly felt at Minto Landing, and across the river in Harrisonmouth, according to Daphne Sleigh, where stores closed down a week after BCER started operating. ${ }^{41}$

Three years later, the Beaver also became a casualty to the BCER. Roy believes the advantage the BCER had was that its terminal in downtown Chilliwack "was nearer to most farms than the steamer landing," and tended to carry other commodities, such as wood, milk, and mail, while the Chilliwack Landing steamers generally carried farm produce, feed, and livestock. Riverboats and trains did not compete directly in many areas, partly due to the specialization in different cargo each carried, and through the special shipping rates each charged their customers. On the other hand, freight carried by the Beaver transferred from CPR trains gave "shippers a better rate than they might otherwise have" which extended from the parent company, on goods originating from or heading to eastern Canada. The Beaver ended service by October 1913, due to the start of BCER overnight service,

\footnotetext{
${ }^{40}$ CP 16 March 1910; CP 8 February 1911; CP 31 October 1918; White, 266; H. Ewert, The Story of the BC Electric Railway Company (Vancouver: Whitecap, 1986) 89.

${ }^{41}$ Roy, 60-61; UBC Special Collections, BCERRC Fonds, Box 111, File 351 "Diaries - Oct 16 31 1911"; Sleigh, 97.
} 
and the arrival of the Canadian Northern Pacific railway in Chilliwack. Additionally, by honouring the special "through rates" from CPR trains, the steamer is estimated to have lost $\$ 7,000$ in the first ten months of $1913 .{ }^{42}$

After the retirement of the Beaver, Captain Seymour, and his purser William Nesbitt from Chilliwack, walked right onboard their old rival, the Paystreak, and operated her for six weeks, before spending the remainder of December 1913 attending sheriffs' auctions and inspecting other steamers to purchase. As 1914 began, Seymour and his crew re-invested. He introduced a new, much smaller boat from northern British Columbia, the SS Skeena, to the Chilliwack - New Westminster run, a new competitor to the BCER, and the last steam powered riverboat to operate between Chilliwack and New Westminister. There were also new investors, a new parent company, and new crew. Seymour made more use of nearby Minto Landing, until loading docks there were carried away by the Fraser River in August 1917. The Skeena had sourced a new, free supply of fuel by arranging with New Westminster sawmills to use their discarded "slab wood." 43

\section{The SS Skeena \& the Final Chapter of Chillwack Landing}

In its final years, the Skeena faced a basic problem of balancing a duty to the diminishing number of farmers who still used the steamer service with finding a suitable price to charge to keep the riverboat running. Historians Pat Roy and George White noted how after the Paystreak and Beaver were finally dispatched, the BCER raised its freight rates and kept them uniformly higher than the Skeena charged, thereby supporting this steamer to remain competitive against railways. Captain Joseph Herrling recalled that "It was more about the weigh landings. Picking up farmers' produce" at riverside locales. The convenience for farmers being located near a steamboat landing was enough to resist the allure which rail offered. $^{44}$

The Skeena became the main link between Fraser Valley produce growers and New Westminster consumers through the 1920s. When this chain was occasionally broken newspapers would duly announce Seymour's riverboat as the cause of the disruption. Anxious newspaper stories would describe how at the Fraser River docks "All along the river from Chilliwack to the city [NW], fruit, vegetables, and stock were awaiting shipment," or "The stranding of the SS Skeena near the Chilliwack Wharf depleted the usual supplies sent down from Fraser Valley points to the weekly market." The poor Skeena was once stuck on a sandbar for nearly a month in 1925, "affecting river transportation service from all points between here

\footnotetext{
${ }^{42}$ Roy, 60, 61; CP 30 April 1913; CP 23 September 1953; CP 24 September 1913; CP 23 September 1942; CA MS 24, File 21; interview Capt H. Young, BC Archives PR-0374 Item T0696 sides 1 and 2.

${ }^{43}$ CP 17 December 1913; CP 23 July 1914; CP 16 August 1917; Charlie Power interview tape 1 side 1, CA MSS 401, CP 5 July 1922.

${ }^{44}$ Roy, 61; G. White, "History of the Eastern Fraser Valley Since 1885," (unpublished MA

Thesis, UBC, 1937), 13; Joseph Herrling, BC Archives, PR-0374 tape T1225, sides 1 and 2.
} 


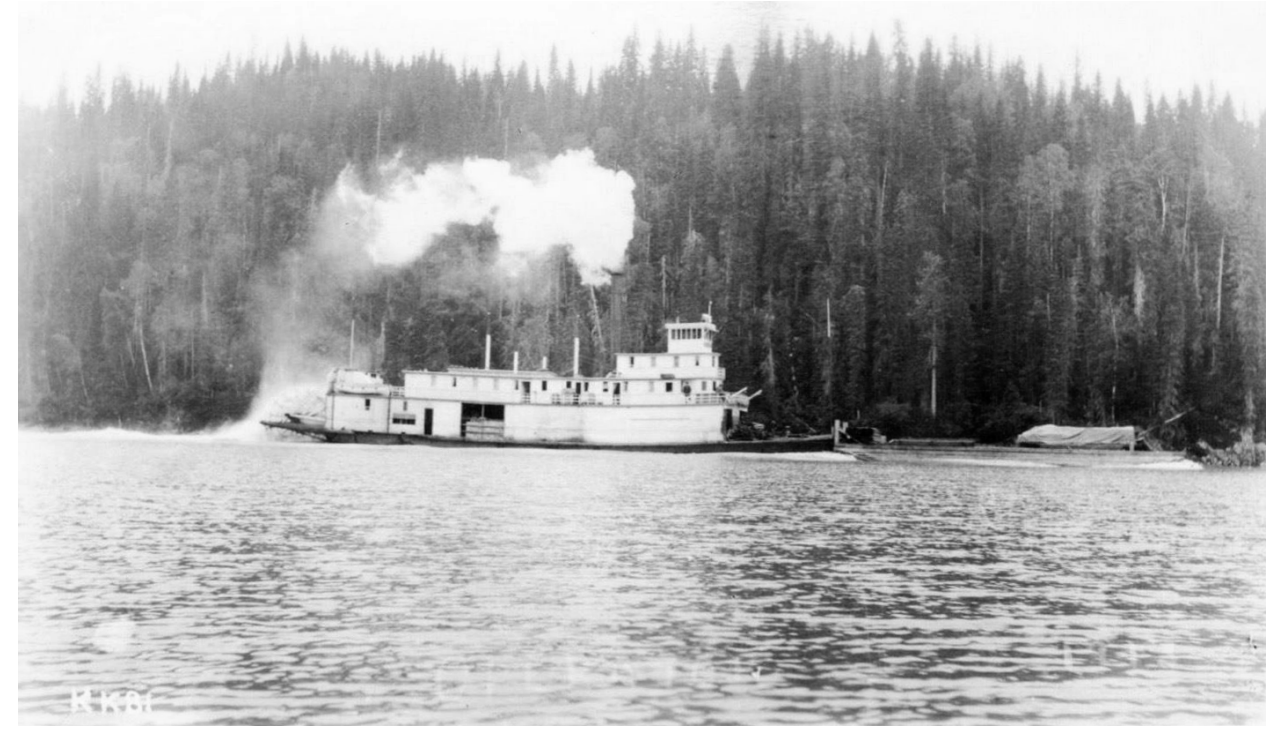

S. S. Skeena

and New Westminster, culminating in a large, widely signed petition to the Chilliwack Board of Trade, urging assistance for the beleaguered vessel. The petition's text reminded urban British Columbians who enjoyed eating low-priced local vegetables that this single remaining Fraser River steamer "means a saving of 100 per cent on freight" for Fraser Valley farmers. The Chilliwack Progress reminded its readers how relevant the Skeena remained for Fraser Valley farmers, that "Fraser River navigation is equally essential from an economic standpoint today $\ldots$ as it was twenty years ago."45

Sometime before 1926, this river steamer passed a threshold of no longer being competitive or financially viable. During her last years on the Fraser River, although she had a capacity of 120 tons, she was only moving on average fifty to sixty tons of freight on the single weekly run between New Westminster and Chilliwack. With static demand for riverboats in the 1920s, other parties who had considered operating a riverboat between Chilliwack and New Westminster withdrew from the idea. Seymour ran the Skeena for reasons other than profit, judged by the steamer's accumulated debts. Therefore the length of time that riverboats used Chilliwack Landing was likely inflated. During the final years of his career, Seymour was somewhat imprisoned to the duty of operating this single remaining riverboat out of obligation to the generations of riverside farmers he had befriended since the 1890s. He had hung in long enough to see the road network emerge, to witness transport trucks compete for traffic with the BCER for the very farmers which his ship had served so faithfully. ${ }^{46}$

${ }^{45} C P 11$ October 1917; CP 5 October 1922; CP 25 February 1925; CP 21 January 1925.

${ }^{46}$ CP 6 January 1926; CP 27 June 1929; CP 1 November 1928. 
Popular and well-liked, Captain Charlie Seymour spent his last Labour Day sleeping aboard his steamer at New Westminster, where the vessel was alongside over the holiday. Seymour "died at his post" on the SS Skeena of a heart attack on 3 September 1928, and the riverboat era at Chilliwack Landing essentially expired along with him. By 1928, the Skeena likely needed major repairs but finding people to repair an old-fashioned sternwheeler was difficult. The boat was eventually seized by creditors and sold "for a song" for debts accumulated from earlier years. Steamboat service at Skwah First Nation met with "a rather ignoble ending" through finally being superseded by other transportation forms, and the whistle of steampowered riverboats at Chilliwack Landing was heard no longer. ${ }^{47}$

47 CP 6 January 1926; CP 6 September 1928; BC Archives GR 2851, Vol 202, Reg\# 29029; CP 25 February 1925; White, "Development," 269. 